\title{
The Effect of Authoritative School Climate on Students' Academic Achievement
}

\author{
Siti Syamimi Ismail, Zuraidah Zainol ${ }^{\mathrm{a}}$ \\ ${ }^{a}$ Faculty of Management and Economics, Universiti Pendidikan Sultan Idris, zuraidah@fpe.upsi.edu.my
}

\begin{abstract}
This study was conducted to determine the effectiveness of authoritative school climate, particularly the disciplinary structure and student support, on student academic achievement. The study adopted a quantitative approach and a sample survey method. 200 students were selected from two secondary schools in Zone 5 Kinta Utara, Ipoh using a systematic sampling method. Multiple linear regressions were used to test the proposed hypotheses. The results show that the student supports have a significant and positive effect on the student's academic achievement, but not disciplinary structure. Accordingly, to boost student achievement, the school administrators should adopt authoritative school climate, specifically by embedding the student support culture among all school teachers and support staffs. Despite the results provide insights on the significance of the authoritative school climate to increase student achievement, this study is subjected to some limitations, which require improvement and replication in the future studies.
\end{abstract}

Keywords:

Academic achievement, authoritative school climate, disciplinary structure, student support

\section{INTRODUCTION}

School is a formal institution where the children obtain their education in order to be successful in the future. More than that, school has become the main place for children as they spend at least six hours of their time every day at school (Kweon \& Ellis, 2012; Lawrence \& Vimala, 2012). Since most of the children age is spent at school, the role of school climate is crucial in shaping the children, including influencing the academic achievement of students (Cornell \& Huang, 2016; Cornell, Shukla \& Konold, 2016).

A school climate is a social system that makes up the learning environment (Moss, 1979). According to Wang and Degol (2015), school climate involves academic, community, security, and institutional environment that affect the cognitive, behavioural and psychological development of a student. Further, the Curriculum Development Centre (1992) highlighted a positive school climate as a good school atmosphere, where the environment is felt comfortable, peaceful and friendly.

A positive school climate is very important that it could improve students' academic performance (Booker, 2006; Watkins \& Aber, 2009). Wang and Holcombe (2010) also highlighted that favourable school climate can significantly affect academic achievement and school involvement. According to Jia, Konold and Cornell (2009), a positive school climate has the capability to increase the students' academic achievement, particularly in reading, writing, and mathematics.

The Ministry of Education (2013) reported that the academic achievement of students in Malaysia is still at a low level compared to other countries in the region. The results of 
major Malaysian public examination, i.e. Sijil Pelajaran Malaysia (SPM) for 2015 also recorded a decline compared to the previous year (Utusan Online, 2016). Due to that, it was stated that the current level of academic achievement is not up to the standard set by the Ministry of Education, which may serve as the main barrier in achieving the vision to make Malaysia as the education excellence hub in the region (Malaysian Digest, 2015).

As to deal with the problem, the Ministry of Education has embarked programs as to create a better school climate whereby all the school community would actively in education development. Such efforts are consistent with the findings of Aziz and Nurfaizah (2010), which emphasized that academic achievement is not only the results of student efforts, but also the support from various parties. Realizing the significance of positive school climate in influencing the student's academic achievement, it is pertinent to delve into the matter in order to gain comprehensive insights.

There are quite a number of studies that investigate the influence of positive school climate on students' academic achievement (Brand, Felner, Seitsinger, Burns, \& Bolton, 2008). Mostof the studies have revealed that positive school climate significantly and positively affect the students' academic achievement (McEvoy \& Welker, 2000; Mok, 2003; Taylor \& Tashakkori, 1995). However, little research has actually defined what is considered as positive school climate until recently there are studies that put forward the authoritative school climate as a positive school climate (Cornell \& Huang, 2016; Cornell et al, 2016; Gregory et al, 2010; Gregory \& Cornell, 2009; Konold et al., 2014).

In those studies, it was found that the two dimensions of authoritative school climate, that is disciplinary structure and student support, could enhance student achievement in the academic (Gregory et al, 2010; Gregory \& Cornell, 2009). The disciplinary structure is a situation where the student perceives that the school rules are fair and reasonable (Cornell et al, 2016). Hence, by applying the disciplinary structure as outlined in the authoritative school climate, students are more willing to comply with the school rules and improve their performance (Tyler, 2006). Furthermore, student support refers to the extent that the students feel that they have received encouragement and supports from the school staff (Konold et al., 2014). If they believed that they have received huge supports, they are more likely to improve their academic achievement (Goodenow, 1993; Gregory, et al, 2011).

Given that limited studies have been done to provide empirical evidence on the role of authoritative school climate on student academic achievement, particularly in Malaysia, this study attempt to examine the effect of authoritative school climate (disciplinary structure and student support) on academic achievement.

\section{LITERATURE REVIEW}

Academic achievement is the indicator of individual achievements in an official examination or public examination taken under the Ministry of Education (MOE) (Othman \& Rahmadhaniah, 2008). According to Johnson (2008), academic achievement is an important factor in learning and personal growth, career development and life planning. The success of a student is also determined by his/her academic achievement (Yip, 2007).

One of the major factors to increase the student academic achievement is the positive school climate (Booker, 2006; Brand, Felner, Shim, Seitsinger, \& Dumas, 2003; Wang \& Holcombe, 2010; Watkins \& Aber, 2009). It was further explained that school environment 
that is perceived as comfortable, peaceful and friendly by students, are more likely to improve the academic achievement of students (Yahaya, \& Majid, 2011). In addition, the recent studies suggested that positive school climate can be indicated as a school that adopted the authoritative school climate (Gregory et al, 2010; Gregory \& Cornell, 2009). In particular, the school that practises strict but fair disciplinary structure, and very supportive to the student, has a significant influence to boost student academic achievement (Cornell et al, 2016; Jia et al., 2009).

Based on the literature, it could be believed that the two dimensions of authoritative school climate, i.e. disciplinary structure and student support, have significant effect on academic achievement. Figure 1 depicts the framework to be tested in this study, in which disciplinary structure and student support serve as independent variables, while academic achievement as the dependent variable.

Independent variables

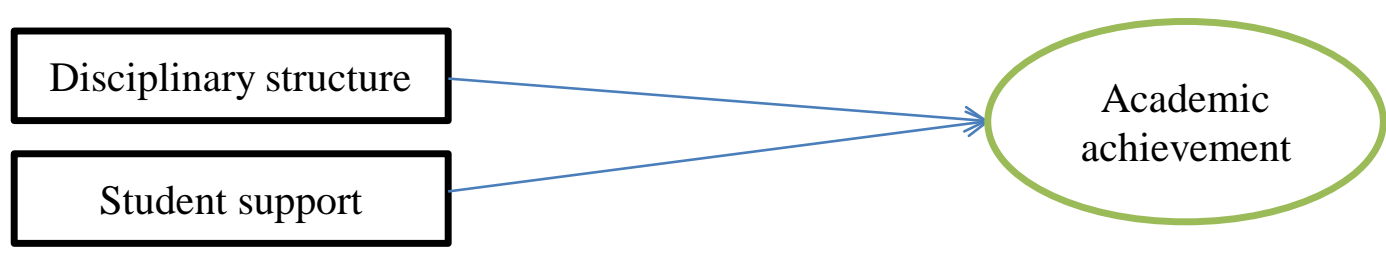

Figure 1: Conceptual framework

\section{METHODOLOGY}

This study employed a quantitative approach and sample survey method. The sample of the study consisted of 200 respondents, who are the selected students from two secondary schools in Zone 5 Kinta Utara, Ipoh. The sample for this study was selected by using a systematic sampling technique. The unit of analysis is the individual students because this study aims to determine the effect of authoritative school climate (disciplinary structure and student support) on academic achievement.

This study used a questionnaire as an instrument to obtain data. The questionnaire was divided into three main sections. Part A consisted of four questions pertaining to demographic factors such as gender, ethnicity, age, and religion; Part B consisted of 15 questions on the perception towards authoritative school climate, in which seven items to measure disciplinary structure, while eight items to measure student support; and Part C consisted of one question on the student academic achievement. The responses in Part B and $\mathrm{C}$ were measured using 7-point Likert scale ranging from 1 (strongly disagree) to 7 (strongly agree).

A pilot study was conducted to determine the problem with the questions and questionnaire, as well as to test the validity and reliability of the instrument (Roslihah, 2006). This pilot study involved 100 respondents. Validity refers to the degree in which the instrument is able to measure what it is supposed to measure, while reliability refers to the consistency of results produced by the instrument (Zimmermann, 2013). 
To test the construct validity, this study examined the Pearson correlation of each questionnaire item score with the total score of the corresponding construct. Items that significantly correlated with total score would indicate that the items are the valid item of the construct. The validity test was not done on academic achievement since it consists of only one construct. The results of the validity test of the authoritative school climate constructs showed the significant correlation for all items towards its corresponding construct with the $r$ values ranging from 0.5 to 0.77 . Thus, the validity was supported.

The reliability test was not done on academic achievement since it consists of only one construct. To test the reliabilityof the authoritative school climate scale, the Cronbach's alpha value was used. The results showed the Cronbach's alpha values from 0.614 to 0.805 , which well above the recommended value of 0.6 (Bond \& Fox, 2007). The results indicated that the scale reliability was supported.

Once the questionnaire was finalized, data were distributed to the selected respondents. Gathered data were then analysed using multiple linear regressions.

\section{FINDINGS}

Table 1 presents the profile of the respondents. Most of the respondents are female, with a total of 119 people (59.5 percent). Majority of them are Malay (155, 77.5\%), followed by Chinese $(34,17 \%)$, Indian $(9,4.5 \%)$. In terms of age, majority is 16 years old $(197,98.5 \%)$.

Table 1: Respondents data distribution

\begin{tabular}{llcc}
\hline \multirow{2}{*}{ Gender } & & Frequency & Percent \\
Ethnic & Male & 81 & 40.5 \\
& Female & 119 & 59.5 \\
& Malay & 155 & 77.5 \\
& Chinese & 34 & 17 \\
& Indian & 9 & 4.5 \\
Age & Other & 2 & 1 \\
& 16 & 197 & 9.5 \\
& 17 & 3 & 1.5 \\
\hline
\end{tabular}

Next, three assumptions of multiple linear regression were examined. The three assumptions are normality, outliers and multicollinearity. Normality is determined by examining the skewness and kurtosis values. According to Garson (2012), the data is distributed normally when the skewness and kurtosis values are within \pm 2 . The results showed one item (i.e. BB3) with kurtosis value exceeding 2. Hence, the item was deleted. With the deletion of the item, the normality assumption was satisfied.

Outliers were detected using the Mahalanobis Distance test. For a model that has two independent variables the alpha $(\alpha)$ value of 0.001 , the maximum value of Mahalanobis Distance should be less than the Chi-square value of 13.8 to indicate no extreme values. The results showed the maximum value of the Mahalanobis Distance is 17.42, which is more than the value of the Chi-square. Then, there are extreme values in the data. Observing the Mahalanobis Distance values, two observations were identified as outliers. Thus, the 
observations were removed. With the removal of the observations, the outliers assumption was fulfilled.

Multicollinearity occurs when there is a high correlation between two or more variables (Andale, 2015). The existence of multicollinearity can be tested using the value of VIF and tolerance. The multicollinearity problem exists when the variance inflation factor (VIF) is greater than 10, (Hair et al., 2010) and the value of tolerance is less than 0.2 (Garson, 2012). The results showed the VIF and tolerance values of 1.766 and 0.566 , respectively. Thus, the multicollinearity problem does not exist in the data.

As the assumptions were satisfied, the multiple linear regression analysis was carried out to meet the objectives of the study, which is to determine the effect of authoritative school climate (disciplinary structure and student support) on academic achievement. The results of the multiple linear regression analysis in Table 2 shows the $R^{2}$ value of 0.193 . This suggests that 19.3 percent variation in the dependent variable (academic achievement) can be explained by authoritative school climate dimensions, i.e. disciplinary structure and student support.

Table 2: Model summary of academic achievement

\begin{tabular}{ccccc}
\hline Model & R & R Square & $\begin{array}{c}\text { Adjusted R } \\
\text { Square }\end{array}$ & $\begin{array}{c}\text { Std. Error of } \\
\text { the Estimate }\end{array}$ \\
\hline 1 & $0.439^{\mathrm{a}}$ & 0.193 & 0.185 & 1.37 \\
\hline
\end{tabular}

ANOVA results in Table 3 showed the $p$-value (0.000) that less than the value of $\alpha$ (0.05). It is clear that at least one of the independent variables is capable of providing a significant effect on the dependent variable (academic achievement) with the $\mathrm{F}(2,195)=$ 23.333 .

Table 3: ANOVA one-way academic achievement

\begin{tabular}{llccccc}
\hline & & Sum of & & & & \\
& Model & Squares & df & Mean Square & F & Sig \\
\hline \multirow{3}{*}{1} & Regression & 87.567 & 2 & 43.783 & 23.333 & $0.000^{\mathrm{b}}$ \\
Residual & 365.913 & 195 & 1.876 & & \\
& Total & 453.48 & 197 & & & \\
\hline
\end{tabular}

Next, the $p$-value and the standardized beta are checked to determine whether there is a significant relationship between the independent variables and the dependent variable. The findings in Table 4 show that the $p$-value $(0.843)$ for disciplinary structure $(\beta=0.017, p>0.01)$ is greater than the alpha value $(0.01)$, indicating an insignificant relationship. Hence, $\mathrm{H}_{01}$ is failed to be rejected, which indicates that there is no relationship between disciplinary structure and academic achievement. Thus, it can be concluded that disciplinary structure has no influence on academic achievement. As for student support, the $p$-value (0.000) is less than the alpha value of 0.01 . Then, $\mathrm{H}_{02}$ is rejected, implying that there is a significant effect of student support on academic achievement. Furthermore, the standardized beta for the effect is positive, indicating that the higher support is perceived by the student, the academic achievement of the student is more likely to improve. 
Table 4: Linear regression coefficient

\begin{tabular}{cccccc}
\hline Model & \multicolumn{2}{c}{$\begin{array}{c}\text { Unstandardized Coefficients } \\
\text { B }\end{array}$} & $\begin{array}{c}\text { Standardized } \\
\text { Std. Error }\end{array}$ & t & Sig. \\
\hline Discipline & 0.028 & 0.142 & 0.017 & 0.198 & 0.843 \\
Support & 0.653 & 0.13 & 0.428 & 5.008 & 0.000 \\
\hline
\end{tabular}

Dependent Variable: Academic Achievement

The summary results of the hypothesis testing are presented in Figure 2.

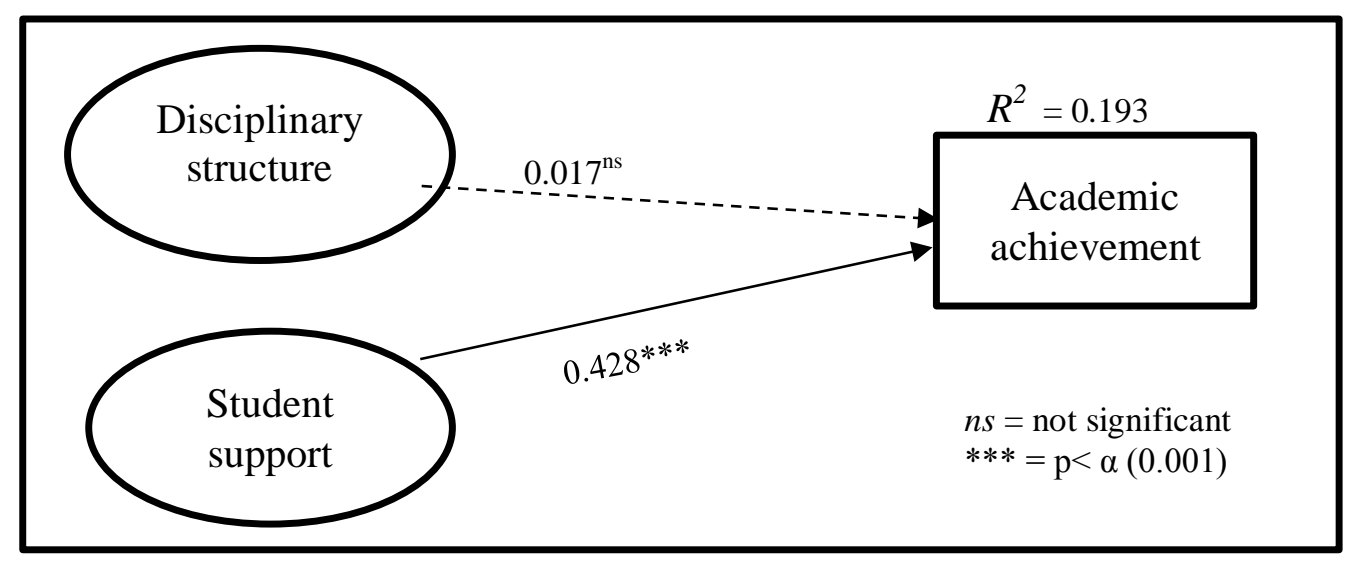

Figure 2: Summary of hypothesis testing results

\section{DISCUSSION}

This study aims to determine the effect of authoritative school climate (disciplinary structure and student support) on academic achievement. The results show that student support significantly and positively affect academic achievement, but the effect of disciplinary structure is insignificant. In other words, the support provided by the school staff plays a major role to boost student academic achievement. The results seem to concur with the previous findings, which indicate that students who were exposed to adults support in school can significantly improve academic achievement (Cornell, et Al., 2016; Goodenow, 1993; Gregory \& Weinstein, 2004).

Thus, the findings of this study partially support the existing literature pertaining to the role of authoritative school climate, especially to enhance academic achievement. Besides, the findings add to the existing literature by confirming student support as one of a major component to create a positive school climate. The added knowledge is expected to trigger further research on authoritative school climate. In addition, the findings provide useful information and guidance to the school administrators, government, private agencies and school community in designing effective programs that can boost student academic achievement.

Despite significant contribution, this study is also subjected to limitation, which require further improvement and replication in future studies. First, future studies could include other outcome variables that have been omitted in this study, such as academic 
engagement and aspiration. Second, future studies could broaden the context, setting and sample selection in order to enhance the generalization.

\section{REFERENCE}

Yahaya, A., \& Majid, N. A. (2011). Hubungan antara budaya formal sekolah dan gaya pembelajaran pelajar dengan pencapaian akademik pelajar sekolah menengah. Journal of Educational Psychology and Counseling, 2(1), 78-112.

Bond, Trevor G, \& Fox, Christine M. (2007). Applying the Rasch Model:Fundamental Measurement in the Human Sciences. Taylor \& Francis Group.

Booker, K.C. (2006). School Belonging and the African American adolescent: what do we know and where should we go?, The High School Journal, 89(4), 1-7.

Brand, S., Felner, R. D., Seitsinger, A., Burns, A., \& Bolton, N. (2008). A large scale study of the assessment of the social environment of middle and secondary schools: The validity and utility of teachers' ratings of school climate, cultural pluralism, and safety problems for understanding school effects and school improvement. Journal of School Psychology, 46(5), 507-535.

Cohen, J., McCabe, L., Michelli, N. M., \& Pickeral, T. (2009). School climate: Research, policy, practice, and teacher education. Teachers college record, 111(1), 180-213.

Cornell, D., \& Huang, F. (2016). Authoritative school climate and high school student risk behavior: A cross-sectional multi-level analysis of student self-reports. Journal of youth and adolescence, 45(11), 2246-2259.

Cornell, D., Shukla, K., \& Konold, T. R. (2016). Authoritative school climate and student academic engagement, grades, and aspirations in middle and high schools. AERA Open, 2(2), 2332858416633184.

Creswell, J. (2008). Education Research. New Jersey: Pearson-Merill Prentice Hall.

Davis, J. A., (1971). Elementary Survey Analysis. Englewood Cliffs, New Jersey: Prentice Hall.

Ghazali, D., \& Sufean, H. (2016). Metodologi penyelidikan dalam pendidikan: Amalan dan analisis kajian, Kuala Lumpur. Universiti Malaya.

Gregory, A., Cornell, D., Fan, X., Sheras, P., Shih, T. H., \& Huang, F. (2010). Authoritative school discipline: High school practices associated with lower bullying and victimization. Journal of Educational Psychology, 102(2), 483.

Goodenow, C. (1993). The psychological sense of school membership among adolescents: Scale development and educational correlates. Psychology in the Schools, 30(1), 7990.

Jia, Y., Konold, T. R., \& Cornell, D. (2016). Authoritative school climate and high school dropout rates. School Psychology Quarterly, 31(2), 289. 
Juani Munir (2016). SPM 2015 menurun berdasarkan GPN. Retrieved April 18, 2017 from http://www.utusan.com.my/berita/nasional/spm-2015-menurun berdasarkan-gpn-1.196881

Jumalinja Abd Jalil (2015). Kualiti perkhidmatan dan kepuasan pelanggan restoren hotel dan syarikat penerbangan di Malaysia. UPSI

Kamaruzaman (2013). Kesahan dan kebolehpercayaan instrumen kajian. Jabatan Pembangunan Pengurus, Pemimpin dan Eksekutif PendidikanInstitut Aminuddin Baki, Genting Highlands.

Kementerian Pendidikan Malaysia (2013). Pelan Pembangunan Pendidikan Malaysia 20132025.

Jia, Y., Konold, T. R., \& Cornell, D. (2016). Authoritative school climate and high school dropout rates. School Psychology Quarterly, 31(2), 289. http://dx.doi.org/10.1037/spq0000062

Malaysian Digest (2015). Ranking pendidikan Malaysia merosot belakang Vietnam. Retrieved Febuary 18, 2017 from http://malaysiandigest.com/bahasamalaysia/553464-ranking pendidikan-malaysia-merosot-belakang-vietnam.html

Moss, W. (1979). Superintendent Leadership Orientations And Its Relationship To School Board Satisfaction. Ed.D. University of Missouri-Columbia.

Ali, N., Habidin, N. F., Jamaludin, N. H., Khaidir, N. A., \& Shazali, N. A. (2013). Customer relationship management and organizational performance in Malaysian healthcare industry. International Journal of Advancements in Research and Technology, 2(1), $1-5$.

Othman \& Rahmadhaniah (2008). Faktor-Faktor Yang Mempengaruhi Pencapaian Akademik Pelajar Tahun 4 Perdana, Jabatan Pendidikan Teknikal Dan Kejuruteraan, Sesi 2007/2008, Fakulti Pendidikan UTM, Skudai.

Roslihah Binti Mat Nor (2006). Kecemerlangan Akedemik Pelajar Sekolah Menengah Harian Biasa: Satu Kajian Kes Di Sekolah Menengah Kebangsaan Tengku Mahmud Besut,Terengganu. Universiti Teknologi Malaysia : Tesis Projek Sarjana Muda.

Sabitha Marican (2006). "Penyelidikan Sains Sosial - Pendekatan Pragmatik." Selangor: Edusystem Sdn Bhd.

Thapa, A., Cohen, J., Guffey, S., \& Higgins-D’Alessandro, A. (2013). A review of school climate research. Review of educational research, 83(3), 357-385.

Tyler, T. R. (2006). Psychological perspectives on legitimacy and legitimation. Annu. Rev. Psychol., 57, 375-400.

Wang, M. T., \& Degol, J. L. (2016). School climate: A review of the construct, measurement, and impact on student outcomes. Educational Psychology Review, 28(2), 315-352. 
Wang, M. T., \& Holcombe, R. (2010). Adolescents' perceptions of school environment, engagement, and academic achievement in middle school. American Educational Research Journal, 47(3), 633-662.

Yip, M. C. W. (2007). Differences in learning and study strategies between high and low achieving university students: A Hong Kong study. Educational Psychology. 25(5), 597-606. 